\title{
National versus international mergers in unionized oligopoly
}

\author{
Kjell Erik Lommerud* \\ Odd Rune Straume** \\ and
}

Lars Sørgard ${ }^{* * *}$

We analyze how the presence of trade unions affects the pattern of mergers in an international oligopoly and the welfare implications thereof. We find that wages for the merger participants are always lower when they merge internationally, rather than nationally. Using a model of endogenous merger formation, we find that the firms will merge internationally in equilibrium. There are more international mergers than socially preferred, unless products are close substitutes. A "national champion" policy of promoting domestic mergers rather than international ones is nevertheless never optimal.

\section{Introduction}

- International mergers increasingly shape the industrial structure of developed and developing economies alike. ${ }^{1}$ This is probably a natural development. At some stage, domestic economies of scale are exhausted. In addition, economic integration means that not only trade but also the market for corporate control is liberalized. The question remains, though, whether firms can also have strategic reasons for choosing an international rather than a national merger. The purpose of this article is to apply an international oligopoly model to analyze how the interplay between the labor market and the product market may affect firms' merger decisions. Could it be that firms merge internationally rather than nationally to curb the market power of trade unions? If so, will we observe a higher number of international mergers than would be optimal seen from a

* University of Bergen and CEPR; kjell-erik.lommerud@econ.uib.no.

** University of Bergen; odd.straume@econ.uib.no.

*** Norwegian School of Economics and Business Administration; lars.sorgard@nhh.no.

We thank two anonymous referees and Editor Joseph E. Harrington Jr. for very helpful comments and suggestions. We have also benefitted from presenting this work at a CEPR conference in Bergen (2003), at the IIOC Conference in Chicago (2004), at a workshop on cross-border mergers at University of Paris 1 (Sorbonne) (2004), and at Stockholm University (2003). We are grateful for financial support from Statoil through the Institute for Research in Economics and Business Administration (SNF) and from the Norwegian Research Council (Globalisation Programme).

${ }^{1}$ Gugler et al. (2003) identify five great merger waves during the past century and point out that the fraction of international mergers has steadily increased. In 1999 the total value of worldwide cross-border mergers and acquisitions amounted to more than $80 \%$ of world FDI flows. In the same year, the share in all mergers and acquisitions that was cross-border, in value terms, reached nearly $31 \%$ (UNCTAD, 2000, 2002). 
welfare point of view, or perhaps that international mergers supplant domestic ones to an excessive degree?

To analyze such questions, a natural starting point would be the existing models on mergers and merger policy in open economies. ${ }^{2}$ However, most of the existing literature is about domestic mergers with spillovers on foreign agents, often focusing on the interplay between merger policy and trade policy. In contrast, we focus on firms' choice between a domestic and a cross-border merger. ${ }^{3}$ Horn and Persson (2001a) suggest that cooperative game theory could be used to pinpoint which industry structure will materialize when many different mergers are possible. We apply this method to solve for the equilibrium market structure when we allow for any two-firm merger in a situation with four firms initially. ${ }^{4}$ As a robustness check, we also describe two versions of a noncooperative acquisition game that yield the same prediction about market structure as the cooperative framework. ${ }^{5}$

The novel feature of the present article is the focus on the interaction between market power in the product market and in the labor market. Already, Brander and Spencer (1988), Davidson (1988), Dowrick (1989), and De Fraja (1993) have suggested that oligopoly power in the product market might be an important reason why trade unions have the potential to influence wage setting. ${ }^{6}$ Empirical studies suggest that mergers in the product market-which leads to higher concentration - may in fact influence wages. But the picture is mixed. Some studies find that a merger leads to higher wages, while others find the opposite result or no effect at all. ${ }^{7}$ Unfortunately, there are few theoretical studies that can guide us on how mergers should be expected to affect wages. Our article helps to fill this gap by showing how different types of mergers can have distinctly different effects on wages and in turn on profits and welfare.

A core idea in our article is that an international merger can tilt the power balance between employers and workers. We study an international Cournot oligopoly with two domestic and two foreign firms, where wages are set by monopoly trade unions. The analysis rests further on the assumption that it is easier for workers to organize within, as opposed to across, national borders. ${ }^{8}$ This notion is most conveniently implemented by letting trade unions be national by assumption: any firm operating in a given economy meets the wage claims of the relevant national union. As long as there are national unions - or at least that unions within a nation cooperate more easily than unions in different countries - then an international merger, as opposed to a national one, will imply that the merged firm meets two uncoordinated unions.

Since we model market power both in the input (labor) and output market, a merger will change both output prices and wages. A national merger makes market shares less sensitive to wage changes, which gives the unions an incentive to raise wages, and more so for the firms not taking part in the merger. An international merger, on the other hand, has a distinctly different

${ }^{2}$ See, e.g., Dixit (1984), Barros and Cabral (1994), Long and Vousden (1995), Head and Ries (1997), Sørgard (1997), Richardson (1999), Horn and Levinsohn (2001), Collie (2003), and Neary (2003, 2004).

${ }^{3}$ Some articles study how firms in one country may access the market in some other country. Cross-border mergers are studied as one alternative way of access, with greenfield investment and exports as alternatives. See Norbäck and Persson (2004), Bjorvatn (2004), and Bertrand (2005).

${ }^{4}$ Horn and Persson (2001b) apply their own method to an international oligopoly situation, but do not consider trade unions. Lommerud, Straume, and Sørgard (2005), Straume (2003), Huck and Konrad (2004), Saggi and Yildiz (2006), Yildiz (2002), and Spearot (2004) also follow the endogenous merger track in international settings.

${ }^{5}$ An alternative to the cooperative route is obviously to model acqusitions as a noncooperative bidding game. See Kamien and Zang (1990) for one such model. Theories of sequential mergers, as in Nilssen and Sørgard (1998), also picture mergers as alternatives to each other.

${ }^{6}$ For recent work on the effect of globalization with international unionized oligopoly, see Naylor (1998), Munch and Skaksen (2002), and Lommerud, Meland, and Sørgard (2003).

${ }^{7}$ Brown and Medoff (1988), Cremieux and Van Audenrode (1996), and Peoples, Hekmat, and Moini (1993) find support for a wage cut following a merger, while McGuckin and Nguyen (2001) find the opposite result. Hekmat (1995) and Gokhale, Groshen, and Neumark (1995) find no or only limited evidence of a link between takeovers and wages.

${ }^{8}$ Formal union cooperation across national borders is rarely observed, due to historical, institutional and cultural factors. In a survey, Marginson and Schulten (2000) conclude that "the development of any pan-European collective bargaining structures to determine pay and major conditions at inter-sector, sector and/or multinational company levels remains a distant prospect." 
effect on the unions' wage setting. An international merger would imply that the merged firm is served by two different unions, each producing input to one of the merged firm's two products. Then the merged firm can partly replace sales of one of its products by increasing the sales of the other product. Since an international merger leads to such a flexibility, it triggers increased competition between the unions. As a result, the unions compete more fiercely on wages. ${ }^{9}$ We also allow for the possibility of exogenous merger synergies in the form of nonlabor cost savings for the merger participants. The presence of such cost savings improves the competitive position of the merged entity, which tends to increase wages for the merger participants and lower wages for the outside firms. However, due to the effects of different types of merger on union rivalry, wages are always lower for the merger participants if they merge cross-border rather than domestically.

Since a national merger has a potential "raising rivals' cost" effect (when nonlabor cost savings are not too large), while an international merger always leads to lower wages for firms not participating in a merger, it is a priori not clear what would be the equilibrium market structure. It turns out, though, that the stable equilibrium market structure always implies that the firms merge internationally. This is the most effective corporate strategy to reduce union rents, thereby leaving a larger surplus in the downstream market.

There are numerous examples of multinational firms that exploit the potential for shifting production between plants in different countries. In Marginson and Schulten (1999) it is documented in detail that in such industries as automobile, electrical consumer products, and food manufacturing products, the plants within multinational firms are engaged in internal competition for both current production and future investments. One example is the German car producer BMW, which acquired the British company Rover in 1994 (see Hall, 1998). In 1998, BMW threatened to close down production at the Rover plant. This led to an agreement where the workers at the Rover plant accepted a package of measures including the elimination of premium payments for overtime and Saturday working. Another example is Electrolux, a Swedish producer of electrical consumer products with plants in many European countries (see Paparella, 1997). It announced in November 1997 that it planned to restructure production in Europe and close down some plants in its subsidiary Zanussi in Italy. In December 1997, Electrolux and the trade union at Zanussi signed an agreement in which it was decided that there would be no plant closures in Italy. The trade union agreed on a package of measures that included lower wages, for example that newly recruited workers would receive a lower wage than the minimum set by company-level bargaining for the first two years. ${ }^{10}$ Norway's dominant chocolate producer Freia recently introduced night shifts, something the union had resisted for decades. Freia is now a subsidiary of the U.S. multinational Kraft Foods. The threat that production could be moved to some other Kraft subsidiary abroad if productivity growth targets were not met was enough to convince the union.

Many have the impression that the role of unions is strongly in decline, which presumably would make a theory of union wage responses to mergers less interesting. However, international evidence is very mixed. OECD (1997) reports union coverage figures for OECD member countries for 1980, 1990, and 1994. ${ }^{11}$ In 1994, the vast majority of OECD countries still had union coverage rates above $70 \%$. The relatively few countries with coverage less than $50 \%$ were the United States, United Kingdom, Canada, New Zealand, and Japan. De-unionization, in the sense of a stark drop in union coverage over the period, is found only in the United Kingdom and in New Zealand. In the United States, coverage is also sliding downward, albeit from a starting point that was very low to begin with. A couple of countries, notably Australia and Portugal, have experienced sharp falls in union membership, but without a corresponding change in union coverage. Leaving the

\footnotetext{
${ }^{9}$ This could be called a "second source" argument, even though this is not second sourcing in a literal sense. The article in the second source literature that is closest to our model (but still quite different) is Choi and Davidson (2004).

${ }^{10}$ In a press release, the trade union stated that "the agreement means most notably that the Italian Zanussi plants have managed to avoid being on the international list of cuts decided by Electrolux" (see Paparella, 1997).

${ }^{11}$ Union coverage refers to the percentage of workers covered by a collective agreement, as opposed to union density, which reports the percentage of workers who are members of unions. In some countries, coverage and density differ substantially, with France as the famous example. There, in 1994, union coverage was 95\%, while union density was $9 \%$.

(C) RAND 2006
} 
Anglo-American sphere, in continental Europe and Scandinavia union coverage is stable and high. ${ }^{12}$ It is true that high union coverage does not necessarily mean that unions are as strong as they were. The theory presented in this article is precisely how some mergers can weaken the position of trade unions and of how firms seek out exactly those mergers. Note also that a theory of mergers in international unionized oligopoly can also be of interest for firms that are based in low-union-coverage countries. For example, U.S. multinationals will often be involved in mergers with firms in unionized countries. To calculate the correct valuation of a possible takeover target in a unionized country, a bidder needs to consider wage responses in the firms in question and in the rest of the industry.

While firms prefer to merge internationally, it is not obvious that this is the correct choice from a global or domestic welfare point of view. A wage reduction is a transfer from workers to employers that by assumption does not influence social welfare by itself. However, lower wages may in turn lead to lower product prices. If so, consumers benefit as well. We find that two international mergers is actually the most preferred market structure from a global welfare perspective if products are sufficiently close substitutes - even if nonlabor cost savings are nonexistentimplying that there is a perfect correspondence between private and social merger incentives in this case. On the other hand, if products are sufficiently differentiated, there will be an excessive number of international mergers.

Many would argue that the aim of competition authorities is not to maximize global social welfare, but rather the domestic social welfare of one's own country. A policy maker must then evaluate to what extent a wage cut in the oligopolized sector is transformed into lower consumer prices rather than higher profits - and to what extent the relevant consumers and capital owners reside in the country in question. International mergers may not always be wanted: in some cases no merger is domestic-welfare optimal, and in others the preferred outcome is a national merger in the foreign country. Our perhaps most interesting result is that a domestic merger is always detrimental to domestic welfare, unless nonlabor cost savings with respect to a merger are sufficiently high. This questions the idea that lax merger policy toward domestic firms, to build up a national champion, would be a good substitute for strategic trade policy. Rather, when the nonintervention outcome needs to be corrected, our analysis points toward strict merger policy as pertains to both domestic and foreign firms as the optimal choice.

The remainder of this article is organized as follows. In Section 2 we present the structural model and explain the merger formation process. The union wage effects of merger - the crucial feature of the model-are analyzed and discussed in Section 3. The profitability of a single twofirm merger is briefly discussed in Section 4, followed by a presentation of the equilibrium market structure in Section 5. Implications for welfare-global and domestic-are discussed in Sections 6 and 7. In Section 8 we extend the model to allow for noncooperative merger formation. Finally, some concluding remarks are offered in Section 9.

\section{The model}

Four ex ante identical firms (owners) are located in two countries, A and B. Owners 1 and 2 are located in country A, whereas owners 3 and 4 reside in country B. Each plant produces a specific brand of a differentiated product, and firms compete in Cournot fashion in a single integrated market. We assume that entry to the industry is restricted, due to some firm-specific ownership advantages of the incumbents.

The market-clearing price of brand $i$ is given by the following inverse-demand function:

$$
p_{i}=a-q_{i}-b \sum_{j} q_{j}, \quad i, j=1, \ldots, 4, i \neq j
$$

where $q_{i}$ is supplied quantity of brand $i$, and $b \in(0,1)$ is an inverse measure of the degree of

12 EEAG (2004) gives 2001 figures for union coverage for a somewhat different set of countries. The impression is that union coverage remained stable during the latter half of the 1990s.

(C) RAND 2006. 
product differentiation. ${ }^{13,14}$ Following Singh and Vives (1984), this demand structure is derived from the maximization problem of a representative consumer whose utility function is given by

$$
U=a \sum_{i} q_{i}-\frac{1}{2}\left(\sum_{i} q_{i}^{2}+b \sum_{i} \sum_{j} q_{i} q_{j}\right)+z, \quad i, j=1, \ldots, 4 ; i \neq j,
$$

where $z$ is a numeraire "outside" good.

The goods are produced by using labor and nonlabor inputs in a fixed proportion, where one unit of brand $i$ requires one unit of labor-at the price $w_{i}-$ and a given amount of nonlabor input(s) - at the price $c$. We further assume that a firm can reduce its nonlabor costs by merging with another firm. Such exogenous merger synergies are captured by assuming that marginal production costs for brand $i$ are given by

$$
w_{i}+c\left(1-D_{i} \mu\right)
$$

where

$$
D_{i}= \begin{cases}0 & \text { if firm } i \text { does not participate in a merger } \\ 1 & \text { if firm } i \text { participates in a merger, }\end{cases}
$$

and $\mu \in[0,1]$ indicates the magnitude of the cost synergy. We preserve the ex ante symmetry of the model by assuming that these synergies can be realized in a merger between any two firms.

Workers are organized in trade unions. A key assumption of the model is that workers are not able to organize across borders, nor are trade unions in different countries able credibly to coordinate their wage demands. ${ }^{15}$ We thus make the assumption that workers are organized in country-specific industrywide unions. ${ }^{16,17}$

We adopt the monopoly union model, where wages in each country are unilaterally set by the respective trade unions. ${ }^{18}$ The objective of each trade union is to maximize total rents for its members,${ }^{19,20}$ implying the following utility functions for the trade unions in countries $\mathrm{A}$ and $\mathrm{B}$, respectively: ${ }^{21}$

$$
\begin{aligned}
& V_{A}=\left(w_{1}-\bar{w}\right) n_{1}+\left(w_{2}-\bar{w}\right) n_{2}, \\
& V_{B}=\left(w_{3}-\bar{w}\right) n_{3}+\left(w_{4}-\bar{w}\right) n_{4},
\end{aligned}
$$

${ }^{13}$ Only with perfect substitutability can a firm simply move the production of a brand from one plant to another.

${ }^{14}$ Lommerud and Sørgard (1997) use a similar demand system but assume that there are fixed costs associated with establishing brands and that the number of brands is an endogenously determined choice variable.

${ }^{15}$ A model that studies possible collusion among trade unions can be found in Straume (2002).

${ }^{16}$ An alternative interpretation of the model is that workers are organized in plant-specific trade unions that coordinate wage setting within - but not across - national borders.

${ }^{17}$ EEAG (2004) documents that the countries in Western Europe that have high union coverage also typically have wage formation predominantly at the industry level-or even more centralized. The main mechanism of the model can survive in such a setting, if enterprise wage formation tends to be coordinated within the firm nationally after a merger, but not internationally.

${ }^{18}$ In the no-merger starting point, this means that all firms are unionized and all unions are equally strong. The theory in this article is not one of capital flight to nonunionized low-cost countries, but of multinationals playing equally strong unions against each other.

${ }^{19}$ The rent-seeking assumption is widely used as a simple union maximand. If workers are risk neutral, it coincides with the idea of a utilitarian union that maximizes the weighted sum of its members' utilities. See Oswald's (1985) famous survey for a discussion of union objectives.

${ }^{20}$ Pemberton (1988) shows that a rent-maximizing union is equivalent to a "managerial union" with union leaders who are interested in size (employment) and union members (represented by the median worker) who are interested in excess wages, where the leadership and workers have equal bargaining power.

${ }^{21}$ The Editor has pointed out that it is important for subsequent results that the cross-derivative of the union maximand as regards wage and employment be nonnegative. If the union utility function is a utilitarian welfare function over its members' utilities, "employment" is simply the number of people who get utility from money. In this case, a negative cross-derivative is implausible. 
where $w_{i}\left(n_{i}\right)$ is the wage (employment) level at plant $i$, and $\bar{w}$ is the outside wage (that can be earned outside the oligopoly industry), assumed to be equal in both countries. Note that each trade union is allowed to set different wages at different plants.

Finally, profits associated with the sale of brand $i$ are given by ${ }^{22}$

$$
\pi_{i}=\left[p_{i}-w_{i}-c\left(1-D_{i} \mu\right)\right] n_{i}, \quad i=1, \ldots, 4
$$

The game is characterized by the following sequence of moves: ${ }^{23}$

Stage 1. The equilibrium ownership structure of the industry is determined through bargaining between the owners.

Stage 2. The trade unions simultaneously and independently set wages.

Stage 3. The firms simultaneously and independently set quantities.

Merger formation. The ownership structure of the industry is assumed to be formed through a cooperative game of coalition formation. We make the assumption that only two-firm mergers are allowed. ${ }^{24}$ Each production plant continues to exist after a merger, and it is not possible to move the production of one brand from one plant to another, so the quintessence of a merger is coordination on output decisions among the participating units. With two-firm mergers, we are left with 6 possible market structures, comprising a combined total of 10 possible ownership structures, that could emerge as an equilibrium outcome. Labelling country A as the "domestic" country, we introduce the following notation to distinguish between the different market structures:

(i) No merger: $M_{0}=\{1,2,3,4\}$.

(ii) One domestic (national) merger: $M_{N}^{d}=\{12,3,4\}$.

(iii) One foreign (national) merger: $M_{N}^{f}=\{1,2,34\}$.

(iv) Two national mergers: $M_{N N}=\{12,34\}$.

(v) One international merger: $M_{I}=\{13,2,4\}, M_{I}^{\prime}=\{14,2,3\}, M_{I}^{\prime \prime}=\{1,23,4\}, M_{I}^{\prime \prime \prime}=$ $\{1,24,3\}$.

(vi) Two international mergers: $M_{I I}=\{13,24\}, M_{I I}^{\prime}=\{14,23\}$.

The solution procedure is based on Horn and Persson (2001a), who treat the merger process as a cooperative game of coalition formation, where the players are free to communicate and write binding contracts. Owners that agree on a merger can decide on any division of the firm's profits, but payments between coalitions are not allowed. The approach then involves a comparison of any two possible ownership structures $M_{i}$ and $M_{j}$, where $M_{i}$ is said to dominate $M_{j}$ if the combined profits of the decisive group of owners are larger in $M_{i}$ than in $M_{j}$. The decisive group of owners comprises the owners that are expected to be able to influence whether $M_{i}$ will be formed instead of $M_{j}$, and vice versa. Given the above assumptions, owners belonging to identical coalitions in the two structures cannot affect whether $M_{j}$ will be formed instead of $M_{i}$, but all remaining owners can influence this choice and are thus decisive. ${ }^{25}$

To give a brief illustration of the main ideas in the model, consider a comparison between the no-merger structure $\left(M_{0}\right)$ and the market structure with one domestic merger $\left(M_{N}^{d}\right)$. In this case

22 To ensure an interior solution, with nonnegative profits for all firms in every possible market structure, we assume that $c<(1 / 2)(a-\bar{w})$.

${ }^{23}$ We implicitly picture that international "liberalization" of the markets just took place, and that there were pre-liberalization national bans on merger to monopoly. The starting point then is four independent firms.

${ }^{24}$ It is straightforward but space-consuming to extend the model to allow for mergers that include three production units. Three-firm mergers are more likely to be blocked by competition authorites, and the present focus on two-firm mergers also makes the distinction between national and international merger more succinct.

${ }^{25}$ See Horn and Persson (2001a) for a formal definition of decisive owners. 
owners 3 and 4 stand alone in both structures, so the decisive owners are the merger participants in $M_{N}^{d}$, i.e., owners 1 and 2, and the dominance relation is determined by whether or not the merger is profitable for the participants. Now consider instead a comparison between a domestic and an international merger, say between $M_{N}^{d}$ and $M_{I}$. For $M_{N}^{d}$ to dominate $M_{I}$ it is not enough that (the domestic) owners 1 and 2 prefer $M_{N}^{d}$ over $M_{I}$. If owner 3 is adversely affected by the formation of $M_{N}^{d}$, this owner may want to persuade owner 1 to form $M_{I}$ instead, by offering a large share of the surplus in this structure. Thus, three owners $(1,2$, and 3$)$ are decisive, and the dominance relation is determined by a comparison of total profits for these three owners in the two ownership structures.

Finally, the solution concept is the core. Those structures that are in the core-i.e., the structures that are undominated-are defined as equilibrium ownership structures (EOS), which then determine the equilibrium market structure (EMS).

\section{Market structures and union wages}

- In this section we present a detailed analysis of union wage responses to different market structures, which to a large extent determines the outcome of the bargaining game between owners. Due to the symmetric nature of the model, we can ease notation by introducing the following notational shorthand: in market structures that involve one or more mergers, $w_{m}^{k}$ and $w_{o}^{k}$ refer to the equilibrium wage level for a merger participant and an outsider, respectively, in market structure $M_{k}$. Similar notation is used for other equilibrium variables throughout. Variables without subscript refer to the symmetric no-merger equilibrium.

Since equilibrium wages depend on the characteristics of the market structure, a merger yields potentially both exogenous and endogenous cost synergies. As will be shown below, the wage effects of mergers are also related to the magnitude of nonlabor cost savings. However, for clarity of exposition, we will start out by discussing the case of no exogenous cost synergies, i.e., $\mu=0$. By a comparison of equilibrium wage expressions for different market structures, with $\mu=0$, we derive the following result. ${ }^{26}$

Proposition 1. $(\mu=0): w_{m}^{N N}>w_{o}^{N}>w_{m}^{N}>w^{0}>w_{o}^{I}>w_{m}^{I}>w_{m}^{I I}$.

Without exogenous merger synergies, there exists an unambiguous ranking of market structures with respect to union wages. Furthermore, using the no-merger structure as a benchmark, a clear pattern arises: union wages are higher in any market structure involving national merger(s), whereas the opposite is true in market structures involving international merger(s). ${ }^{27}$

The intuition behind these results can be found through a more careful scrutiny of the unions' maximization problem. Consider the first-order conditions for optimal wage setting by the trade union in country A, given by

$$
n_{i}(\cdot)+\left(w_{i}-\bar{w}\right) \frac{\partial n_{i}(\cdot)}{\partial w_{i}}+\left(w_{j}-\bar{w}\right) \frac{\partial n_{j}(\cdot)}{\partial w_{i}}=0, \quad i, j=1,2 ; i \neq j,
$$

where $n_{i}(\cdot)$ is the derived labor demand at firm $i$. Obviously, the first-order conditions for optimal wage setting by the trade union in country $\mathrm{B}$ are completely equivalent.

From (6) we see that the relationship between market structures and union wages potentially works through two different channels. Mergers affect the wage level at firm $i$ insofar as either the demand for labor or the wage responsiveness of labor demand (the slope of the labor demand curve)-evaluated at the pre-merger equilibrium wage level-changes as a result of the merger.

\footnotetext{
${ }^{26}$ Expressions for equilibrium wages, employment, and profits in each market structure are reported in Appendix A.

${ }^{27}$ Lommerud, Straume, and Sørgard (2005) discuss how downstream mergers might influence the prices charged by upstream firms (e.g., trade unions) with market power. In that article, we show that the main results, broadly speaking, carry over to models with wage bargaining and/or Bertrand competition. Although the frameworks are different, the main mechanisms are similar, so we expect this to be true also in the present framework.
} 
More specifically, a reduction (increase) in labor demand, or more (less) wage-responsive labor demand, induces the trade union to set a lower wage.

For comparative purposes, the labor demand of firm $i$ in $M_{0}$ is given by

$$
n_{i}^{0}(\cdot)=\frac{(2-b)(a-c)-2(1+b) w_{i}+b \sum_{j \neq i} w_{j}}{4+4 b-3 b^{2}}, \quad i=1, \ldots, 4 .
$$

On the other hand, labor demand for merger participants and outside firms in a market structure with one merger are given by ${ }^{28}$

$$
\begin{aligned}
& n_{m}^{k}(\cdot)=\frac{(2-b)(a-c)+(2+b) \mu c-\frac{(1+b)(2-b)}{(1-b)} w_{m}+\frac{2 b}{(1-b)} w_{-m}+b \sum w_{o}}{2\left(2+3 b-b^{2}\right)}, \\
& n_{o}^{k}(\cdot)=\frac{2(a-c(1+b \mu))-\frac{2\left(2+2 b-b^{2}\right)}{(2-b)} w_{o}+\frac{2 b}{(2-b)} w_{-o}+b \sum w_{m}}{2\left(2+3 b-b^{2}\right)},
\end{aligned}
$$

$k=N, I$. In market structures with two mergers, labor demand for a merger participant is given by ${ }^{29}$

$$
n_{m}^{k}(\cdot)=\frac{2(a-c(1-\mu))-\frac{(2+b(2-b))}{(1-b)} w_{m}+\frac{b(2+b)}{(1-b)} w_{-m}+b \sum w_{m^{\prime}}}{4(1+2 b)},
$$

$k=N N, I I$.

Consider first the wage effects of a national merger. A merger reduces the degree of product market competition. With no exogenous cost synergies, this naturally causes labor demand to fall for the merger participants. However, reduced product market competition also implies that the equilibrium market shares of firms are less responsive to wage changes, which-since each trade union controls both $w_{m}$ and $w_{-m}$ in market structures with national mergers - translates directly into less wage-responsive labor demand for each trade union. This is easily confirmed by a comparison between (7) and (8)-(10). When labor demand gets less wage responsive, the trade unions respond by increasing wages, and this effect always dominates the effect of a merger on total labor demand. ${ }^{30}$ Naturally, this effect is also stronger in the market structure with two national mergers.

In the case of just one national merger, Proposition 1 confirms that wages are lower in the country of the merger participants. This is due to the effect of the merger on labor demand for the merging and nonmerging firms, respectively. At the pre-merger wages, the merged firm has an incentive to cut back on production, which implies a reduction of labor demand. The outside firms - being free-riders on the merger-have opposite incentives. In fact, comparing (8) and (9) at the no-merger equilibrium, with $\mu=0$, we find that $n_{m}^{k}=(1-b / 2) n_{o}^{k}$. This labor demand effect causes wages to be lower for the merged firm, and the effect is stronger the less differentiated products are. Consequently, there is a "raising rivals' costs" effect of a national merger in this case.

Now consider an international merger. The crucial feature of such a merger is that the merged firm is able to scale production up at one plant and down at the other, and the two plants involved rely on labor supply from different trade unions. When the trade unions are not able to control both $w_{m}$ and $w_{-m}$, this means that labor demand from each plant of the merged firm gets more responsive to wage differentials between the two trade unions. The result is lower wages for the internationally merged firm. The strength of this effect depends on the substitutability of products in demand. The less differentiated the products are, the more intense is the merger-induced

\footnotetext{
${ }^{28}$ The pairs of merger participants and outside firms are labelled $(m,-m)$ and $(o,-o)$, respectively.

${ }^{29}$ The pairs of merger participants are labelled $(m,-m)$ and $\left(m^{\prime},-m^{\prime}\right)$.

${ }^{30}$ This effect of reduced product market competition on the wage sensitivity of labor demand is also identified, in a somewhat different setting, by Dowrick (1989). 
competition between the trade unions. From (8) we see that $\lim _{b \rightarrow 1}\left(\partial n_{m}^{I} / \partial w_{m}\right) \rightarrow-\infty$, implying that all union rents will be competed away in the merged firms if products are homogeneous.

In market structures with just one international merger, wages will also decrease for the outside firms, compared with the case of no merger. This is a labor demand effect. Since $\partial n_{o}^{k} / \partial w_{m}>0$, lower wages for the merged firm will reduce labor demand at the nonmerged firms. Consequently, the trade unions will respond by lowering wages also for firms not participating in the merger. Obviously, this effect also is stronger the less differentiated products are.

Exogenous merger synergies. How does the presence of exogenous cost synergies influence the wage effects of mergers? From (8)-(10) we see that nonlabor cost synergies affect total labor demand in an unambiguous manner. More specifically, we see that

$$
\frac{\partial n_{m}^{k}(\cdot)}{\partial \mu}>0 \text { and } \quad \frac{\partial n_{o}^{k}(\cdot)}{\partial \mu}<0 .
$$

The intuition is relatively straightforward. Nonlabor merger synergies imply a reduction of marginal production costs. Ceteris paribus, the profit-maximizing response by the merged firm is to increase production, which implies an increase in the demand for labor. In the case of one merger, the outside firms are affected through the improved competitive position of the merged firm. Since production quantities are strategic substitutes, exogenous merger synergies willceteris paribus - lead to a reduction of labor demand for the outside firms. Since $\mu$ does not affect the slope of the labor demand curves, the (partial) effects of nonlabor cost savings on union wages follow immediately: wages increase for the merger participants and decrease for the outside firms.

When allowing for exogenous merger synergies we can no longer make an unambiguous ranking of market structure with respect to equilibrium wages. However, a relatively clear pattern can still be established.

Proposition 2. (i) $w_{m}^{N}>w_{i}$ for all $\mu \in[0,1]$, (ii) $w_{i}>w_{m}^{I}$ if $\mu<\bar{\mu}:=[(4+b)(2-b) b(a-$ $c-\bar{w})] /[8 c(1-b)(4-b)]$, and (iii) $\min \left\{w_{m}^{N}, w_{m}^{N N}\right\}>\max \left\{w_{m}^{I}, w_{m}^{I I}\right\}$ for all $\mu \in[0,1]$.

Parts (i) and (ii) of the proposition show the wage effect of a national and an international merger, respectively. A national merger always leads to increased wages for the merger participants. In fact, since $\partial w_{m}^{k} / \partial \mu>0$, the presence of nonlabor synergies reinforces the wage effect already established in Proposition 1. For an international merger, on the other hand, the opposite holds true. In this case, the presence of nonlabor cost savings introduces two opposing forces on union wage responses to a merger. An international merger thus leads to higher wages for the merger participants if nonlabor cost savings are sufficiently large. Since the union-rivalry effect is increasing in $b$, an international merger is more likely to result in higher wages when products are more differentiated. Furthermore, a certain degree of product differentiation is necessary for the nonlabor cost savings effect to dominate the union rivalry effect. Indeed, we see that $\lim _{b \rightarrow 0} \bar{\mu} \rightarrow 0$ and $\lim _{b \rightarrow 1} \bar{\mu} \rightarrow \infty$.

Part (iii) of the proposition contains the most important result of this section, though. It confirms that-when comparing market structures with national and international merger(s) wages for the merger participants are always lower when they merge internationally. Both types of merger may cause wages to rise, but when compared with national mergers, the intensified interunion rivalry brought about by cross-border mergers always has a dampening effect on wages for the merger participants.

\section{Merger profitability and free-rider effects}

Before deriving the equilibrium of the endogenous merger game, it is instructive to consider how a merger affects profits for merger participants and outside firms. To place the model in a relevant context, we can relate our analysis to two basic findings in the existing merger literature.

First, with exogenous (and linear) production costs we know that a certain degree of product differentiation is necessary in order to make a two-firm merger in Cournot oligopoly profitable 
(see, e.g., Deneckere and Davidson, 1985, and Lommerud and Sørgard, 1997). In a Cournot model, a merger without cost savings will lead the merging parties to contract their output, while outsiders expand. The more differentiated products are, the less the merged unit loses market share to outsiders, and for sufficient differentiation a merger is profitable even in the Cournot case. Second, a purely anticompetitive merger (which yields no cost synergies) is typically more profitable for firms not participating in the merger. This free-rider effect is frequently referred to as the "merger paradox" (see also Salant, Switzer, and Reynolds, 1983).

Consider first the effect of a single international merger. Using the no-merger equilibrium as a benchmark, a straightforward comparison of equilibrium profits (see Appendix A) produces the following result.

Proposition 3. (i) $\pi_{m}^{I}>\pi^{0}$ for all $\mu \in[0,1]$, (ii) $\pi_{m}^{I}>\pi_{o}^{I}$ for all $\mu \in[0,1]$, and (iii) $\pi^{0}>\pi_{o}^{I}$ if $\mu>\widehat{\mu}:=\left[\left(20-b^{2}\right)(1-b) b(a-c-\bar{w})\right] /[12(2-b)(3 b+2) c]$.

An international merger is always profitable for the participants, even if $\mu=0$. This is of course due to the wage effect of such a merger. As shown in the previous section, the wage reduction is larger the less differentiated products are, which helps explain why this effect is sufficiently large to make an international merger profitable for every degree of product differentiation. Furthermore, it is always more profitable to take part in an international merger, rather than being an outsider, implying that the merger paradox is not a feature of an international merger in our model. Indeed, if there are additional nonlabor cost synergies from a merger (i.e., $\mu>0$ ), an international merger may actually be harmful for outside firms, as indicated by part (iii) of the proposition. We see that $\widehat{\mu}=0$ if $b=1$, implying that $\mu>0$ is a sufficient condition for outside firms to lose profits from the merger if products are homogeneous.

The profitability of a national merger, on the other hand, is not easily characterized analytically. Instead, we illustrate the profit effects of such a merger in Figure 1, for some given parameter values. The different areas in the figure are defined as follows:

$$
\begin{aligned}
& \mathrm{A}: \pi_{m}^{N}<\pi^{0}<\pi_{o}^{N}, \\
& \mathrm{~B}: \pi^{0}<\pi_{m}^{N}<\pi_{o}^{N}, \\
& \mathrm{C}: \pi^{0}<\pi_{o}^{N}<\pi_{m}^{N}, \\
& \mathrm{D}: \pi_{o}^{N}<\pi^{0}<\pi_{m}^{N} .
\end{aligned}
$$

We observe the following general pattern: a higher degree of product differentiation and larger nonlabor cost savings increase the likelihood of a national merger being profitable $(B+C+D)$, a national merger being more profitable for the participants than for outside firms $(C+D)$, and a national merger reducing the profits of outside firms (D). The effect of nonlabor cost savings from the merger is obvious. In the absence of such cost savings, a national merger can still be profitable,

FIGURE 1

PROFIT EFFECTS OF A NATIONAL MERGER WHEN $a=1$ AND $\bar{w}=c=1 / 4$

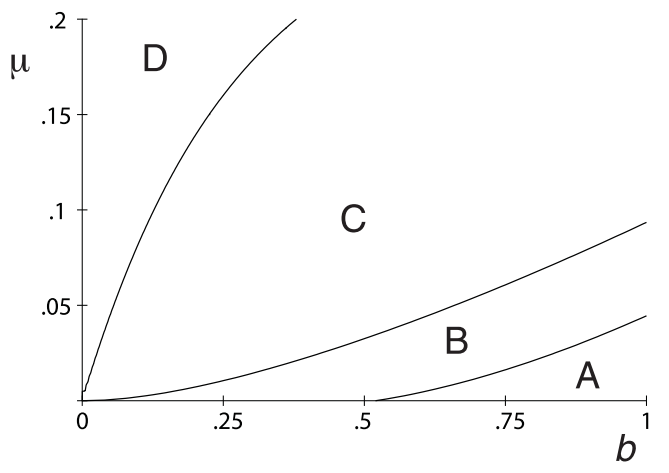


provided that the benefit of output coordination outweighs the wage increase following such a merger. This is the case if products are sufficiently differentiated, which reduces the possibility of outsiders to free-ride on the merger. ${ }^{31}$

\section{Equilibrium market structure}

- We now turn to the equilibrium solution of the full game. A comparison of the relevant profit expressions along the lines of the solution procedure sketched in Section 2 yields the following unambiguous result.

Proposition 4. The equilibrium market structure is two international mergers for all parameter configurations.

Proof. We can show that $M_{I I}$ dominates all other market structures, making it the unique equilibrium market structure. Due to the symmetry of the model, the dominance relations are determined by the following conditions: $M_{I I}$ dom $M_{I}$ if $\pi_{m}^{I I}>\pi_{o}^{I} ; M_{I I}$ dom $M_{0}$ if $\pi_{m}^{I I}>\pi^{0} ; M_{I I}$ dom $M_{N N}$ if $\pi_{m}^{I I}>\pi_{m}^{N N} ; M_{I I}$ dom $M_{N}$ if $2 \pi_{m}^{I I}>\pi_{m}^{N N}+\pi_{o}^{N N}$. The fulfillment of these conditions is confirmed by straightforward algebra. Q.E.D.

The intuition behind this result is naturally related to the wage effects of different types of merger. Regarding the firms' choice between merging domestically or internationally, the market structure with two international mergers dominates any market structure involving national merger(s) if the former structure yields higher industry profits. This is, in turn, dependent on how different types of merger affect the power struggle between employers and workers. As we have shown in Section 3, the effective market power of trade unions is lower when firms merge internationally rather than domestically, which implies that a larger share of the oligopoly rents is extracted by the firms in the former case. ${ }^{32}$

Furthermore, for two international mergers to constitute an equilibrium market structure, the second merger must be privately profitable. For low degrees of product differentiation, and in the eventual absence of nonlabor cost savings, this requires that the merger produce a sufficient saving of wage costs. Since the trade unions will keep wages relatively high in firms that are not internationally merged, there is always a sufficient potential for wage cost savings to make the second international merger profitable for the participants.

Obviously, due to the symmetry of the model, there are multiple equilibria, where the equilibrium market structure is the set of two ownership structures, in both of which all owners merge internationally.

\section{Global welfare}

With regard to social welfare, the analysis of the previous section immediately raises the following question: Will the "merger market forces" lead to socially desirable market structures? The answer to this question is obviously important in determining the optimal framing of merger policy in open economies, and in this section we will highlight the implications for global welfare - defined as the sum of consumers' surplus, profits, and union utility - by making a social ranking of market structures. Formally, global welfare in market structure $M_{k}$ is given by

$$
W_{k}=U_{k}-\sum_{i=1}^{4} p_{i}^{k} q_{i}^{k}+\sum_{i=1}^{4} \pi_{i}^{k}+V_{A}^{k}+V_{B}^{k}
$$

${ }^{31}$ Different parameter configurations would produce a picture that is qualitatively similar to Figure 1. It is easily shown that for $\mu=0$, the sign of equilibrium profit differences is independent of the parameters $a, c$, and $\bar{w}$. For $\mu>0$, numerical simulations suggest that the curves in Figure 1 never cross in the valid $(\mu, b)$-space.

${ }^{32}$ By assuming a global market, a potentially important implication of domestic mergers is ignored. If domestic markets were partially protected by trade costs, the market-power effect might make domestic mergers more profitable. See also Horn and Persson (2001b) for an analysis of domestic versus international merger - in a nonunionized setting -in the presence of trade costs and segmented markets. 
which simplifies to

$$
W_{k}=U_{k}-\left[\bar{w}+c\left(1-D_{i} \mu\right)\right] \sum_{i=1}^{4} n_{i}^{k} .
$$

Note that the welfare function weighs incomes of different groups in society equally. Wage payments and payments for goods therefore appear as mere transfers of money that do not influence social welfare. In consequence, welfare is decided solely by the value to consumers of the goods produced less the opportunity costs of the labor and nonlabor resources used as inputs.

A comparison of global welfare in the different market structures yields the following key results.

Proposition 5. (i) $M_{I I}$ is always socially preferable to any market structure involving national merger(s). (ii) $M_{I I}$ is the socially optimal market structure for all $\mu \in[0,1]$ if $b>.56$.

Proof. See Appendix B.

The first part of the proposition implies that national mergers are never socially optimal, from a viewpoint of global welfare. Such mergers may increase global welfare, if nonlabor cost synergies are sufficiently large, but market structures involving national merger(s) are always socially dominated by the market structure with two international mergers. Furthermore, two international mergers is the socially optimal market structure if the degree of product differentiation is sufficiently low, regardless of the size of nonlabor cost savings. A comparison of Propositions 4 and 5 reveals a perfect correspondence between private and social merger incentives for this case of relatively homogeneous goods.

The reason international mergers can be socially optimal here-even if $\mu=0$-while they would not be in a model with exogenous production costs, is that the power struggle between labor and capital not only lowers wages, but may also cause consumer prices to fall as a result. Since national mergers have no such effect on wages, rather the opposite, they will never be socially preferable unless nonlabor cost synergies are sufficiently large. But even if these synergies are large enough to make national mergers welfare improving, the efficiency gains from international mergers are always larger, due to the union wage effects.

An illustration of how the socially optimal market structure depends on the key parameters $b$ and $\mu$ is given in Figure 2 for a specific numerical example. We see that $M_{I I}$ is the socially optimal market structure if the degree of product differentiation is sufficiently low $(b>.56)$ or nonlabor merger synergies are sufficiently large. In this specific example, nonlabor cost savings of more than $2 \%$ are sufficient to make $M_{I I}$ the optimal structure for every degree of product differentiation.

On the other hand, if the exogenous merger synergy is nonexistent, or very low, the socially optimal market structure is determined by the degree of product differentiation. For intermedi-

\section{FIGURE 2}

SOCIALLY OPTIMAL MARKET STRUCTURES $a=1$ AND $\bar{w}=c=1 / 4$

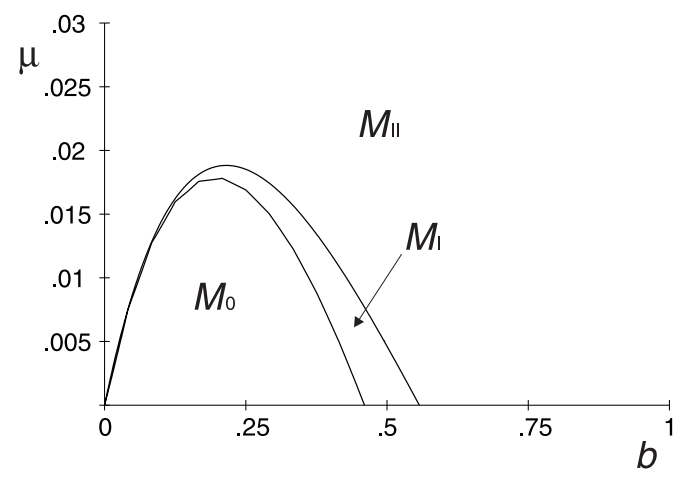


ate levels of differentiation, one international merger is socially preferable, whereas any merger reduces global welfare if products are sufficiently differentiated. The intuition is relatively straightforward: if $\mu=0$, mergers can improve welfare only if they lead to reduced consumer prices, at least for some brands. We know that only cross-border mergers can lead to such price reductions, provided that wages are sufficiently reduced as a result of the merger(s). More specifically, the wage reductions must outweigh the effect of increased market concentration. Since the strength of the wage effect is decreasing in the degree of product differentiation, the market concentration effect is more likely to dominate the wage effect the more differentiated products are. Consequently, $M_{I}$ and $M_{0}$ are socially optimal for intermediate and low levels of differentiation, respectively.

\section{Domestic welfare}

- The evaluation of different market structures from a perspective of domestic welfare may differ significantly from evaluations with respect to global welfare. ${ }^{33}$ To analyze the impact of mergers on domestic welfare, we make a couple of additional assumptions. First, we assume that domestic consumers' surplus constitutes a fraction $\alpha \in[0,1]$ of global consumers' surplus. Second, we assume that profits are divided evenly between the owners taking part in a merger. ${ }^{34}$ Domestic welfare in market structure $M_{k}$ is then given by

$$
W_{k}^{A}=\sum_{i=1}^{2} \pi_{i}^{k}+V_{A}^{k}+\alpha\left(U-\sum_{i=1}^{4} p_{i}^{k} q_{i}^{k}\right)
$$

Consider first the case of no exogenous cost savings from a merger. Figure 3 depicts the pattern of the most-preferred market structure in the $(b, \alpha)$ plane when $\mu=0 .{ }^{35}$ Comparing Figures 2 and 3, we see that there is no conflict between domestic and global interests, from a welfare point of view, as long as a sufficiently high share of consumers resides in the domestic country. The domestically optimal market structure is then one (two) international merger(s) for intermediate (high) levels of product differentiation, and no merger otherwise, precisely as a concern for global welfare would dictate. However, if $\alpha$ is sufficiently low, the domestically most-preferred market structure is a foreign national merger, which harms consumers but benefits domestic firms and workers through higher wages, employment, and profits.

An equivalent illustration for the case of a 5\% nonlabor merger synergy is provided in Figure 4 for a specific numerical example. Again, comparing with Figure 2-which is based on the same numerical example-we see that the presence of nonlabor cost savings increases the correspondence between domestic and global interests. From both perspectives, the optimal market structure is two international mergers, unless a relatively low share of consumers resides in the domestic country and products are sufficiently close substitutes in demand. In the latter case, a foreign national merger is still the most preferred structure, from a domestic point of view.

Figures 3 and 4 illustrate a potential conflict, though, when it comes to coordination of domestic antitrust policies across different countries, particularly for the case of nonexistent or very low nonlabor merger synergies. Assume that a large share of the consumers, say $\alpha=.8$, resides in country $\mathrm{A}$, and consider the case of $\mu=0$. In this case, the most preferred market structure for country A is one (two) international merger(s) if the degree of product differentiation is intermediate (high), and no merger otherwise. However, if $80 \%$ of consumers live in country

${ }^{33}$ Konrad and Lommerud (2001) warn that any preferential treatment of domestic firms can be manipulated in the following sense: foreign owners may sell their assets to domestic owners who then receive favorable treatment, but this only makes the domestic buyers willing to pay a higher price for the assets in question, so the real beneficiaries are the original foreign owners.

${ }^{34}$ With the geographic distribution of owners fixed, $\alpha$ of course becomes a measure of the extent to which consumers relative to capital owners reside in the home country.

${ }^{35}$ When $\mu=0$, the parameters $a, \bar{w}$, and $c$ can be factored out of the welfare expressions, implying that the social ranking of different market structures does not depend on the numerical values of these parameters.

(c) RAND 2006 . 
FIGURE 3

DOMESTICALLY MOST-PREFERRED MARKET STRUCTURE WHEN $\mu=0$

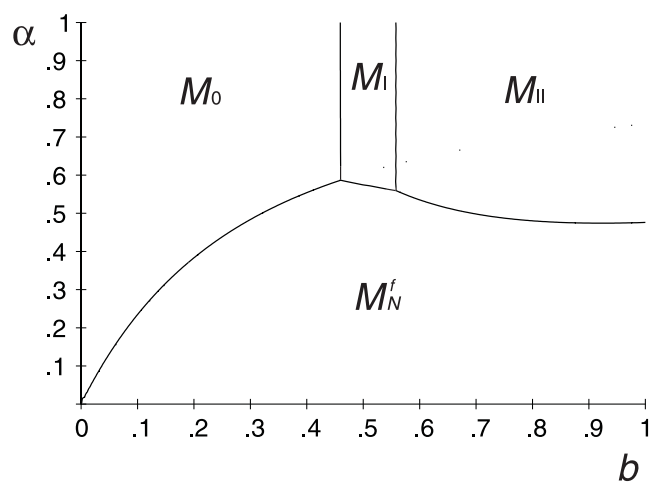

A, then at most $20 \%$ of consumers in this market live in country B, and this country would consequently prefer a foreign national merger.

Finally, we want to highlight the effect of a domestic merger on domestic welfare. Under which circumstances will such a merger improve domestic welfare?

Proposition 6. There exists $\bar{\mu}>0$ such that a domestic merger is detrimental to domestic welfare when $\mu<\bar{\mu}$.

The proof lies in a straightforward evaluation of $W_{N(d)}^{A}-W_{0}^{A}$ and $W_{N N}^{A}-W_{N(f)}^{A}$.

Assume that there are no exogenous merger synergies, i.e., $\mu=0$. In this case, the proposition implies that if national competition policy is governed by considerations for domestic welfare, as defined by (13), the antitrust authorities should never allow a domestic merger. This holds even if $\alpha=0$, which means that the proposed merger's effect on consumers' surplus is irrelevant for domestic welfare. Thus, even if a domestic merger is profitable, the decrease in domestic union rents, due to a loss of employment, more than outweighs the increase in profits. Such a merger benefits domestic welfare only if nonlabor cost savings are sufficiently large. Note also that it can be shown that even when a domestic merger is welfare improving, it will still not be part of the most preferred market structure from a domestic welfare viewpoint, in line with Figures 3 and 4.

For the case of $\mu=0$, this result mirrors the result in Brander and Spencer (1985). They found that a government should pay a subsidy to a domestic firm operating in a foreign Cournot market. The subsidy is a commitment device that helps the firm behave more aggressively and

\section{FIGURE 4}

DOMESTICALLY MOST-PREFERRED MARKET STRUCTURE

WHEN $\mu=.05, a=1$, AND $\bar{w}=c=1 / 4$

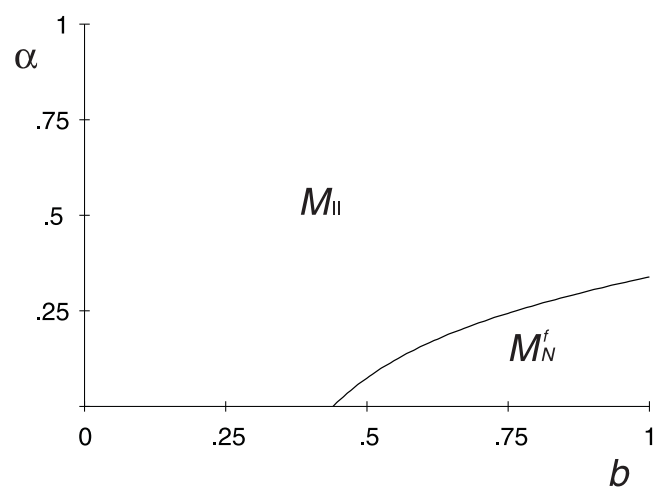


shift profits to its own country. In our setting, a national merger results in higher wages, which is the opposite of paying a subsidy to the firm. This implies that the Cournot firm operating in a foreign market is committed to act less aggressively when it faces higher wages after the merger, thereby reducing the combined sum of profits and union rent. This result questions the idea that lax domestic merger policy can substitute for strategic trade policy or other activist industrial policies to build up national champions. The above reasoning tells us that the nonintervention market structure outcome may not be the domestic welfare optimal one. But if there is a problem, the problem is too many international mergers, not that one would want domestic mergers instead of international ones. Strict merger policy toward all kinds of mergers should then be the choice, not lax merger policy only for domestic mergers.

\section{Noncooperative merger formation}

In the previous analysis we applied a cooperative merger formation model first introduced in Horn and Persson (2001a). In many markets, though, merger formation resembles a noncooperative game. For example, firms merge as a result of an acquisition. In this section we introduce two simple versions of a noncooperative acquisition game and compare our results with the ones reported in Section 5. In line with the previous analysis, we restrict the attention to two-firm mergers, i.e., one firm acquiring only one other firm.

First, let us consider a sequential acquisition game, which is played in two stages according to the following rules: at each stage, one firm is given the role as an initial bidder. ${ }^{36}$ It decides to bid or not on a target firm of its own choice. If it bids, then other firms not already involved in an acquisition can also bid for the target. We assign firm 1 the role of initial bidder at stage 1 . It decides whether or not to make a bid, and chooses the target firm if it decides to bid. Furthermore, firm 2 is the initial bidder at stage 2 if it was not the target at stage 1 . Otherwise, firm 3 is the initial bidder at stage 2 . If a firm is indifferent between bidding and not bidding, we assume that the firm bids. The game is illustrated in Figure 5, where we have specified the profits for the bidder and the target, respectively. Note that when there are two acquisitions, the profits of the stage- 2 bidder and target are listed before the corresponding stage-1 profits.

In Appendix B we show that the outcome of such an acquisition game is two international acquisitions, which is identical to the outcome of the cooperative merger model. This should not be a surprise. As shown in the previous sections, the firms that merge internationally will always be better off, and it is always better to be an insider than an outsider. Note, though, that in this particular setting the target firm at stage 1 and the bidder firm at stage 2 are the ones with the highest profit. The latter firm gains from no competition from other bidders, while the target firm at stage 1 gains from competition for being an acquiring firm at stage 1 and thereby avoiding being a target at stage 2 . However, the two remaining firms (the bidder at stage 1 and the target at stage 2) are also better off compared with the case if no acquisitions at all.

Second, let us also consider a simultaneous acquisition game. To simplify, we assign the roles as bidders to firms 1 and 3. They decide simultaneously whether or not to make bids for the two target firms. Each of the acquiring firms can bid on both target firms ( 2 and 4), but one bidder can only acquire one firm. As we show in Appendix B, the equilibrium outcome of this game is also two international acquisitions. Each target firm receives the profits it could have earned by turning down the offer, while the two bidding firms capture the remaining profits generated by two international acquisitions.

We summarize our result as follows.

Proposition 7. Two international acquisitions is the equilibrium outcome of the described noncooperative acquisition games.

${ }^{36}$ Both in this game and the subsequent simultaneous game, one could imagine an initial stage where there was a lottery to determine which role each firm should have. This would preserve the symmetry of the model, and all firms would have the same ex ante profit.

(c) RAND 2006 . 
FIGURE 5

PROFITS OF THE BIDDER (B) AND THE TARGET $(T)$

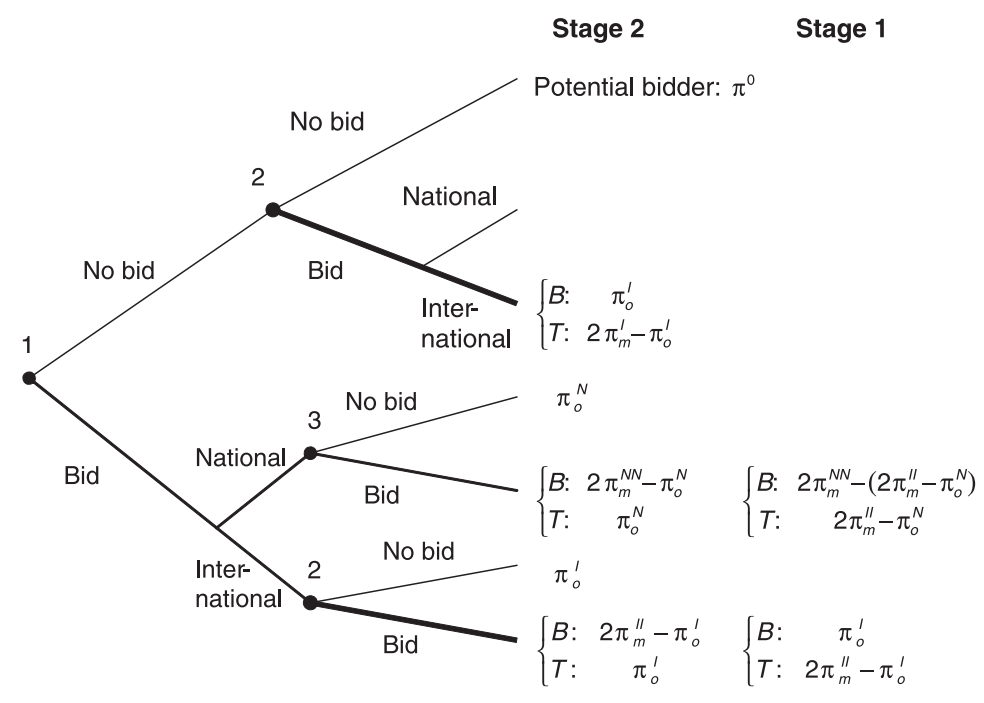

\section{Some concluding remarks}

- In this article we have explored how the presence of trade union power can affect the pattern of mergers in an international oligopoly. A core idea is that a merger triggers wage changes. Our model can then be seen as a merger model with endogenous costs. But in contrast to the received literature, a merger may affect costs for all firms in the industry. ${ }^{37}$ This has important implications for merger policy. Farrell and Shapiro (1990) argued that a sufficient criterion for a merger to improve welfare is that it leads to lower product prices. They propose a simple criterion for when a merger results in lower product prices. ${ }^{38}$ It specifies how large the reduction in the merging firm's marginal costs must be for consumer prices to fall. If the merging firm lowers product prices, the nonmerging firm is expected to do the same. However, our results illustrate that such a criterion can be misleading, because marginal costs change for the nonmerging firms as well. One cannot consider only the merging firm's pricing decision to tell whether consumers benefit or not. For example, with an international merger one could have that the merging firm sets a higher output price while the nonmerging firm sets a lower output price. By using the Farrell and Shapiro criterion for that particular example, one would only concentrate on the merged firm's price increase and forget the outside firm's price cut. In fact, the output price of a nonmerging firm may change even if the output price of the merging firm does not.

According to our predictions, a national merger is expected to lead to higher wages, while an international merger is expected to have the opposite effect on wages, at least if nonlabor cost savings are not too large. It is an empirical question whether this in fact happens. Unfortunately, there are no empirical studies that test for the wage effect of an international versus a national merger. One recent study, though, can shed some light on the issue. Gugler and Yurtoglu (2004) test empirically how mergers affect employment. They found that in the United Kingdom, a domestic merger reduces employment by much more than cross-border deals made by U.K. acquiring firms. This is consistent with a prediction saying that national mergers are more wageincreasing than cross-border mergers. However, apart from the fact that there is no direct link

37 The first study that introduced internal cost savings following a merger was Perry and Porter (1985). A merger resulted in an internal change in how firms operated their crucial assets. It triggered lower marginal costs, but only for the merged firm.

${ }^{38}$ Farrell and Shapiro (1990) consider only an industry with identical products. Werden (1996) extends their criterion to the case of an industry with differentiated products.

(c) RAND 2006. 
between employment effects and wage changes, one should be careful with the interpretation of their results, since their study is not tailored to test the predictions from our theory. ${ }^{39,40}$ This calls for more detailed empirical studies. The structure of the labor market should be taken into account when testing directly for wage effects following different kinds of mergers. This is an issue for future research.

Finally, it is important to stress that our conclusions are reached within a fairly stylized modelling framework. Thus, we cannot claim a high degree of generality for all of our results. However, the main contribution of our article is the identification of certain mechanisms that might be important in explaining merger patterns in unionized international oligopolies: in essence, how cross-border merger might be an effective mechanism for firms to curtail trade union power and thereby obtain wage cost savings. These mechanisms are related to demand substitutability of products, and thus indirectly labor, and clearly generalize beyond the linear specification of demand and cost functions. On the other hand, the precise implications of these wage effects, with respect to merger profitability and welfare, obviously depend on the relative strengths of different opposing forces, which are determined by the exact specification of market structure, technology, and preferences.

\section{Appendix A}

- Equilibrium expressions for employment, wages, and profits in the different market structures follow.

$\square \quad$ No merger $\left(\boldsymbol{M}_{\mathbf{0}}\right)$. Equilibrium employment, wages, and profits for a firm in $M_{0}$ are given by

$$
\begin{aligned}
n^{0} & =\frac{(2+b)(a-c-\bar{w})}{4(2+3 b)}, \\
w^{0} & =(1 / 4)[(2-b)(a-c)+\bar{w}(2+b)], \\
\pi^{0} & =\frac{(a-c-\bar{w})^{2}(b+2)^{2}}{16(3 b+2)^{2}} .
\end{aligned}
$$

One national merger $\left(\boldsymbol{M}_{\boldsymbol{N}}\right)$. Equilibrium employment, wages, and profits for merger participants and outsiders in $M_{N}$ are given by

$$
\begin{aligned}
& n_{m}^{N}=\frac{(2+b)\left[\left(2+2 b-b^{2}\right)(a-c-\bar{w})+\mu c(2+3 b)\right]}{2\left(2+3 b-b^{2}\right)\left(4+6 b+b^{2}\right)}, \\
& n_{o}^{N}=\frac{(1+b)\left[\left(4+4 b-b^{2}\right)(a-c-\bar{w})-\mu c b(2+b)\right]}{2\left(2+3 b-b^{2}\right)\left(4+6 b+b^{2}\right)}, \\
& w_{m}^{N}=\frac{\left(2+2 b-b^{2}\right)(a-c)+2 \bar{w}(1+b)^{2}+\mu c(2+3 b)}{4+6 b+b^{2}}, \\
& w_{o}^{N}=\frac{\left(4+4 b-b^{2}\right)(a-c)+\bar{w}(2+b)(2+3 b)-\mu c b(2+b)}{2\left(4+6 b+b^{2}\right)}, \\
& \pi_{m}^{N}=\frac{(2+b)^{2}(1+b)\left[\left(2+2 b-b^{2}\right)(a-c-\bar{w})+\mu c(2+3 b)\right]^{2}}{4\left(4+6 b+b^{2}\right)^{2}\left(2+3 b-b^{2}\right)^{2}}, \\
& \pi_{o}^{N}=\frac{(b+1)^{2}\left[\left(4+4 b-b^{2}\right)(a-c-\bar{w})-\mu c b(b+2)\right]^{2}}{4\left(4+6 b+b^{2}\right)^{2}\left(2+3 b-b^{2}\right)^{2}} .
\end{aligned}
$$

Two national mergers $\left(\boldsymbol{M}_{\boldsymbol{N} N}\right)$. Equilibrium employment, wages, and profits for a merger participant in $M_{N N}$ are given by

$$
n_{m}^{N N}=\frac{(1+b)[a-\bar{w}-c(1-\mu)]}{2(1+2 b)(2+b)}
$$

${ }^{39}$ There are no data to control for the structure of the labor market, and when comparing national and international mergers, they do not distinguish between related and unrelated mergers. Only in the former do we expect that market power in the product market matters. Note also that for continental Europe, they found only minor differences in the employment effect of national and international mergers.

${ }^{40}$ As pointed out by the Editor, there is also a potential problem of selection bias in such studies, as firms choose to merge cross-border as opposed to domestically, which may influence the wage effects.

(c) RAND 2006 


$$
\begin{aligned}
w_{m}^{N N} & =\frac{a+\bar{w}(1+b)-c(1-\mu)}{2+b}, \\
\pi_{m}^{N N} & =\frac{[a-\bar{w}-c(1-\mu)]^{2}(1+b)^{3}}{4(2+b)^{2}(1+2 b)^{2}} .
\end{aligned}
$$

One international merger $\left(\boldsymbol{M}_{\boldsymbol{I}}\right)$. Equilibrium employment, wages, and profits for merger participants and outsiders in $M_{I}$ are given by

$$
\begin{aligned}
& n_{m}^{I}=\frac{(2-b)\left[\left(8-b^{2}\right)(a-c-\bar{w})+c \mu\left(8+6 b-b^{2}\right)\right]}{2\left(2+3 b-b^{2}\right)\left(16-12 b+b^{2}\right)}, \\
& n_{o}^{I}=\frac{(4-b)\left(2-b^{2}\right)(a-c-\bar{w})-\mu c 3 b(2-b)}{\left(2+3 b-b^{2}\right)\left(16-12 b+b^{2}\right)}, \\
& w_{m}^{I}=\frac{2(1-b)[2(2-b)(a-c)+\mu c(4-b)]+\bar{w}\left(8-3 b^{2}\right)}{16-12 b+b^{2}}, \\
& w_{o}^{I}=\frac{(2-b)[(4-3 b)(a-c)-\mu c b]+2 \bar{w}\left(4-b-b^{2}\right)}{16-12 b+b^{2}}, \\
& \pi_{m}^{I}=\frac{(2-b)^{2}(1+b)\left[\left(8-b^{2}\right)(a-c-\bar{w})+\mu c\left(8+6 b-b^{2}\right)\right]^{2}}{4\left(16-12 b+b^{2}\right)^{2}\left(2+3 b-b^{2}\right)^{2}}, \\
& \pi_{o}^{I}=\frac{\left[(4-b)\left(2-b^{2}\right)(a-c-\bar{w})-3 \mu c b(2-b)\right]^{2}}{\left(16-12 b+b^{2}\right)^{2}\left(2+3 b-b^{2}\right)^{2}} .
\end{aligned}
$$

Two international mergers $\left(\boldsymbol{M}_{\boldsymbol{I I}}\right)$. Equilibrium employment, wages, and profits for a merger participant in $M_{I I}$ are given by

$$
\begin{aligned}
n_{m}^{I I} & =\frac{(2+b)[a-\bar{w}-c(1-\mu)]}{2(1+2 b)(4-b)}, \\
w_{m}^{I I} & =\frac{2(1-b)[a-c(1-\mu)]+\bar{w}(2+b)}{4-b}, \\
\pi_{m}^{I I} & =\frac{[a-\bar{w}-c(1-\mu)]^{2}(2+b)^{2}(1+b)}{4(4-b)^{2}(1+2 b)^{2}} .
\end{aligned}
$$

\section{Appendix B}

- Proofs of Propositions 5 and 7 follow.

Proof of Proposition 5. (i) Using the equilibrium expressions reported in Appendix A, and the definition of global welfare given in (11), we can derive

$$
W_{I I}-W_{N N}=\frac{[a-\bar{w}-c(1-\mu)]^{2} b\left(24+41 b-9 b^{2}-8 b^{3}\right)}{2(4-b)^{2}(2+b)^{2}(1+2 b)}>0
$$

and

$$
W_{I I}-W_{N}=\frac{b^{2} \Omega(a-c-\bar{w})^{2}+\mu c(2+b)(2(a-c-\bar{w}) \Phi+\mu c \Psi)}{4\left(2+3 b-b^{2}\right)^{2}\left(6 b+b^{2}+4\right)^{2}(4-b)^{2}(1+2 b)^{2}},
$$

where

$$
\begin{aligned}
& \Phi=896+6912 b+20872 b^{2}+29644 b^{3}+15954 b^{4}-5583 b^{5}-8408 b^{6}-222 b^{7}+1409 b^{8}-110 b^{9}-26 b^{10} \\
& \Psi=896+6272 b+16104 b^{2}+16356 b^{3}-52 b^{4}-10954 b^{5}-4642 b^{6}+1407 b^{7}+751 b^{8}-98 b^{9}-18 b^{10} \\
& \Omega=1760+10736 b+22876 b^{2}+16356 b^{3}-6147 b^{4}-10673 b^{5}+26 b^{6}+1880 b^{7}-190 b^{8}-30 b^{9}
\end{aligned}
$$

It is easily verified that $\Phi, \Psi$, and $\Omega$ are all nonnegative for $b \in(0,1)$, which implies that $W_{I I}-W_{N}>0$.

(ii) It remains to verify that $W_{I I}>\max \left\{W_{I}, W_{0}\right\}$ for $b>.56$. We have that

$$
W_{I I}-W_{I}=\frac{b \Lambda(a-c-\bar{w})^{2}+\mu c(2 F(a-c-\bar{w})+\mu c \Upsilon)}{4\left(2+3 b-b^{2}\right)^{2}\left(16-12 b+b^{2}\right)^{2}(4-b)^{2}(1+2 b)^{2}},
$$


where

$$
\begin{aligned}
\Lambda= & -6144+2304 b+35328 b^{2}-23888 b^{3}-47312 b^{4}+55140 b^{5}-7192 b^{6}-13101 b^{7} \\
& +6763 b^{8}-1238 b^{9}+78 b^{10}, \\
\Upsilon= & 28672+73728 b-79616 b^{2}-224640 b^{3}+127808 b^{4}+174032 b^{5}-147412 b^{6}+24380 b^{7} \\
& +6459 b^{8}-2297 b^{9}+186 b^{10}-2 b^{11}, \\
F= & 28672+100352 b+20480 b^{2}-192640 b^{3}-42896 b^{4}+160496 b^{5}-21772 b^{6}-42298 b^{7} \\
& +19153 b^{8}-2581 b^{9}+2 b^{10}+14 b^{11} .
\end{aligned}
$$

The denominator in (B3) is obviously positive for $b \in(0,1)$, so the sign of $\left(W_{I I}-W_{I}\right)$ is determined by the sign of the numerator. Within the relevant range of $b$ it is easily verified that $\Lambda>0$ if $b>.56, \Upsilon>0$ if $b<.78$, and $F>0$ for $b \in(0,1)$. The sign of the second term in the numerator of (B3) can be determined by noting that both $F$ and $\Upsilon$ reach their minimal value on $[0,1]$ at $b=1$. It follows that if $(2 F(a-c-\bar{w})+\mu c \Upsilon)>0$ for $b=1$, then $(2 F(a-c-\bar{w})+\mu c \Upsilon)>0$ for $b \in(0,1)$. Setting $b=1,2 F(a-c-\bar{w})+2 \mu c \Upsilon$ reduces to $18(2998(a-c-\bar{w})-1039 c \mu)$, which is positive for $c<(1 / 2)(a-\bar{w})$. It follows that $W_{I I}-W_{I}>0$ for $\mu \in[0,1]$ if $\Lambda>0$, which is true for $b>.56$.

Finally, we have that

$$
W_{I I}-W_{0}=\frac{(2+b)\left[(2 b-1) \Gamma(a-c-\bar{w})^{2}+4 \mu c \Theta(2(a-c-\bar{w})+\mu c)\right]}{8(4-b)^{2}(2 b+1)^{2}(3 b+2)^{2}},
$$

where

$$
\begin{aligned}
& \Gamma=b\left(48+126 b+25 b^{2}-73 b^{3}+6 b^{4}\right)>0, \\
& \Theta=\left(14+21 b-11 b^{2}\right)(3 b+2)^{2}>0 .
\end{aligned}
$$

We see that $W_{I I}-W_{0}>0$ for $\mu \in[0,1]$ if $b>1 / 2 . \quad$ Q.E.D.

Proof of Proposition 7. Consider first the sequential acquisition game. We solve the game by backward induction. At stage 2 there are three possibilities:

(i) No bid at stage 1. Firm 2 is the designated bidder. If it does not bid, there will be no acquisitions, and profits are $\pi^{0}$ for all firms. If firm 2 chooses to bid on another firm, the other domestic firm (firm 1) or one of the foreign firms ( 3 or 4 ) will be the target. First, let us assume that firm 2 bids on firm 1. If firm 2 acquires firm 1, total profits for the two firms would be $2 \pi_{m}^{N}$. However, the two foreign firms can also bid. If one of them wins, total profits for those two firms will be $2 \pi_{m}^{I}$. Since $2 \pi_{m}^{I}>2 \pi^{0}$, firm 1 will accept a bid of $\pi^{0}+\varepsilon$ from either of the foreign firms ( 3 or 4 ). But such a bid is not an equilibrium, since the other foreign firm will have an incentive to bid higher. In fact, a bidding competition between the two foreign firms would result in a bid of $B=2 \pi_{m}^{I}-\pi_{o}^{I}$, which is the reservation bid for each of the foreign firms. The initial bidder will not find it profitable to match such a bid. It knows that if it does not win, it earns $\pi_{o}^{I}$, while if it wins, it earns $2 \pi_{m}^{N}-B$. Its reservation bid would then be $B=2 \pi_{m}^{N}-\pi_{o}^{I}$. Since $2 \pi_{m}^{I}>2 \pi_{m}^{N}$, we will observe an international rather than a national acquisition. Second, let us assume that firm 2 decides to bid on firm 3, which is a firm in the foreign country. From the above discussion we see that it can succeed with such an acquisition if it bids $B=2 \pi_{m}^{I}-\pi_{o}^{I}$, making a profit of $\pi_{o}^{I}$. Since $\pi_{o}^{I}>\pi^{0}$, this implies that making a bid would make firm 2 is strictly better off, and there will be an international acquisition in equilibrium.

(ii) A national acquisition at stage 1. Firm 1 acquires firm 2 at stage 1, and there is no longer the possiblity of an international acquisition. At stage 2, there will either be no acquisition or a national acquisition. If firm 3 decides not to bid, there will be no acquisition, and its profit is equal to $\pi_{o}^{N}$. On the other hand, if firm 3 wants to acquire firm 4 , it has to bid $B \geq \pi_{o}^{N}$, which are the profits of the target firm in case of no acquisition. The acquiring firm will then earn $2 \pi_{m}^{N} N-\pi_{o}^{N}$. Since $2 \pi_{m}^{N N}-\pi_{o}^{N}>\pi_{o}^{N}$ only for some parameter values, the outcome is generally ambiguous.

(iii) An international acquisition at stage 1. If firm 2 decides not to bid, then there will be no acquisition. In such a case its profit is equal to $\pi_{o}^{I}$. On the other hand, if firm 2 wants to acquire the available (foreign) target, it has to bid $B \geq \pi_{o}^{I}$, making a profit of $2 \pi_{m}^{I I}-\pi_{o}^{I}$. Since $2 \pi_{m}^{I I}-\pi_{o}^{I}>\pi_{o}^{I}$ for all parameter values, there will be an international acquisition in equilibrium.

Turning now to stage 1 of the game, there are two possibilities to consider:

(i) No bid at stage 1. We know from the above analysis that if no acquisition occurs at stage 1, there will be an international acquisition at stage 2. It implies that firm 2 acquires either firm 3 or 4 , and firm 1 is the outsider, making a profit of $\pi_{o}^{I}$. 
(ii) A bid at stage 1. The bidding firm can bid either on a national or an international firm at stage 1 . We will discuss each of those alternatives. To simplify the presentation, let us assume that if a national acquisition occurs at stage 1 , there will be a second national acquisition at stage 2 . It can easily be shown that our conclusion will not change if we assumed that there would be no second national acquisition. If firm 1 bids on firm 2, then firm 4 will be the one of the two remaining firms with the lowest profits if firm 1 succeeds, earning $\pi_{o}^{N}$. Its reservation bid for firm 2 at the first stage of the game will then be $B=2 \pi_{m}^{I I}-\pi_{o}^{N}$. Firm 1 can only succeed if it matches such a bid. If so, it earns $2 \pi_{m}^{N N}-\left(2 \pi_{m}^{I I}-\pi_{o}^{N}\right)$. Similarly, if firm 1 bids on firm 3 , firm 4 will be the one of the remaining two firms with the lowest profits if firm 1 succeeds. If it succeeds, firm 4 earns $\pi_{o}^{I}$. Its reservation bid will then be $B=2 \pi_{m}^{I I}-\pi_{o}^{I}$. Firm 1 can only succeed if it matches such a bid. If so, it earns $2 \pi_{m}^{I I}-\left(2 \pi_{m}^{I I}-\pi_{o}^{I}\right)=\pi_{o}^{I}$. By comparison we see that firm 1 will be better off with a bid on firm 3 rather than firm 2 if $\pi_{o}^{I}>2 \pi_{m}^{N N}-\left(2 \pi_{m}^{I I}-\pi_{o}^{N}\right)$. It can easily be verified that this is always true, which implies that we will observe an international acquisition, if any, at stage 1 of the game.

Finally, we have to check whether there will be any acquisition at all at stage 1 . We see that firm 1's profit is $\pi_{o}^{I}$, both in the case of no bid and in the case of a bid on firm 3. Given that each firm by assumption would bid if it were indifferent, firm 1 will bid at stage 1 and make an international acquisition.

Now consider the simultaneous acquisition game. Our procedure is to show that a unilateral deviation is profitable in all cases, except for the market structure with two international acquisitions.

(i) No acquisitions. Firm 1 will obviously find it profitable to bid $\pi^{0}$ on the target firm 4 and earn $2 \pi_{m}^{I}-\pi^{0}>0$.

(ii) One national acquisition. Assume that firm 1 bids on firm 2. It must offer firm 2 at least $\pi^{0}$, and firm 1 can earn at most $2 \pi_{m}^{N}-\pi^{0}$. But then firm 3 will deviate. It can bid $\pi^{0}+\varepsilon$ and earn $2 \pi_{m}^{I}-\pi^{0}-\varepsilon$, which is strictly better than $\pi_{o}^{N}$.

(iii) One international acquisition. As explained in the discussion of stage 2 of the sequential game, the second initial bidder will find it profitable to deviate by acquiring the second target.

(iv) Two national acquisitions. Each of the bidders can earn at most $2 \pi_{m}^{N N}-\pi_{o}^{N}$ by bidding $\pi_{o}^{N}$, the outside option for the target firm. However, a bidder can deviate by bidding $\pi_{o}^{N}+\varepsilon$ for the other target firm, earning $2 \pi_{m}^{I}-\pi_{o}^{N}-\varepsilon$. Since $2 \pi_{m}^{I}>2 \pi_{m}^{N N}$, this deviation is profitable if $\varepsilon$ is sufficiently close to zero.

(v) Two international acquisitions. Each of the bidders can earn at most $2 \pi_{m}^{I I}-\pi_{o}^{I}$ by bidding $\pi_{o}^{I}$. A bidder can deviate by bidding $\pi_{o}^{I}+\varepsilon$ for the other target firm, earning $2 \pi_{m}^{N}-\pi_{o}^{I}-\varepsilon$. Since $2 \pi_{m}^{I I}>2 \pi_{m}^{N}$, such a deviation is not profitable. Furthermore, since $2 \pi_{m}^{I I}-\pi_{o}^{I}>\pi_{o}^{I}$, it is not profitable to withdraw its own bid and be an outsider firm in a market with one international acquisition.

Q.E.D.

\section{References}

Barros, P. and Cabral, L. "Merger Policies in Open Economies.” European Economic Review, Vol. 38 (1994), pp. 1041-1055.

Bertrand, O. "Effects of Economic Integration on Greenfield Investment and Cross-Border M\&A Location Pattern: Theoretical Strategical Analysis and Simulation." Manuscript, TEAM, University of Paris I, 2005.

Bjorvatn, K. "Economic Integration and the Profitability of Cross-Border Mergers and Acquisitions." European Economic Review, Vol. 48 (2004), pp. 1211-1226.

Brander, J.A. ANd Spencer, B.J. "Export Subsidies and International Market Share Rivalry." Journal of International Economics, Vol. 18 (1985), pp. 83-100.

- AND _ "Unionized Oligopoly and International Trade Policy." Journal of International Economics, Vol. 24 (1988), pp. 217-234.

Brown, C. AND Medoff, J.L. “The Impact of Firm Acquisition on Labour.” In A. Auerbach, ed., Corporate Takeovers: Causes and Consequences. Chicago: University of Chicago Press, 1988.

Choi, J.P. And Davidson, C. "Strategic Second Sourcing by Multinationals." International Economic Review, Vol. 45 (2004), pp. 579-600.

Collie, D. "Mergers and Trade Policy Under Oligopoly." Review of International Economics, Vol. 11 (2003), pp. 55-71.

Cremieux, P.-Y. and Van Audenrode, M. “Mergers and Bargaining in the Airline Industry.” Labour, Vol. 10 (1996), pp. 297-318.

DAVIDSON, C. “Multi-Unit Bargaining in Oligopolistic Industries.” Journal of Labor Economics, Vol. 6 (1988), pp. 397422.

De Fraja, G. "Staggered vs. Synchronized Wage Setting in Oligopoly." European Economic Review, Vol. 37 (1993), pp. 1507-1522.

Deneckere, R. AND Davidson, C. "Incentives to Form Coalitions with Bertrand Competition." RAND Journal of Economics, Vol. 16 (1985), pp. 473-486.

Dixit, A. "International Trade Policy for Oligopolistic Industries." Economic Journal, Vol. 94, Supplement: Conference Papers (1984), pp. 1-16.

DowrICK, S. “Union-Oligopoly Bargaining.” Economic Journal, Vol. 99 (1989), pp. 1123-1142.

(C) RAND 2006. 
EEAG (European Economic Advisory Group). Report on the European Economy 2004. Munich: CESifo, 2004.

Farrell, J. AND Shapiro, C. "Horizontal Mergers: An Equilibrium Analysis.” American Economic Review, Vol. 80 (1990), pp. 107-126.

Gokhale, J., Groshen, E., And Neumark, D. “Do Hostile Takeovers Reduce Extramarginal Wage Payments?” Review of Economics and Statistics, Vol. 77 (1995), pp. 470-485.

Gugler, K. And Yurtoglu, B.B. "The Effects of Mergers on Company Employment in the USA and Europe." International Journal of Industrial Organization, Vol. 22 (2004), pp. 481-502.

- Mueller, D.C., Yurtoglu, B.B., And Zulehner, C. “The Effects of Mergers: An International Comparison." International Journal of Industrial Organization, Vol. 21 (2003), pp. 625-653.

Hall, M. “Agreement on Flexible Working Arrangements at Rover." EIROnline, December 28, 1998. Available at www. eiro.eurofound.eu.int/1998/12.

Head, K. And RIES, J. "International Mergers and Welfare Under Decentralized Competition Policy." Canadian Journal of Economics, Vol. 30 (1997), pp. 1104-1123.

Некмат, A. "The Effects of Different Types of Mergers on Union and Non-Union Wages in the United States." Journal of Economics, Vol. 21 (1995), pp. 65-69.

Horn, H. And Levinsohn, J. “Merger Policies and Trade Liberalisation.” Economic Journal, Vol. 111 (2001), pp. 244276.

- ANd Persson, L. "Endogenous Mergers in Concentrated Markets.” International Journal of Industrial Organization, Vol. 19 (2001a), pp. 244-276.

AND - "The Equilibrium Ownership of an International Oligopoly." Journal of International Economics, Vol. 53 (2001b), pp. 244-276.

Huck, S. And Konrad, K.A. "Merger Profitability and Trade Policy." Scandinavian Journal of Economics, Vol. 106 (2004), pp. 107-122.

Kamien, M.I. And Zang, I. “The Limits of Monopolization Through Acquisition.” Quarterly Journal of Economics, Vol. 105 (1990), pp. 465-499.

KonRaD, K.A. AND Lommerud, K.E. “Foreign Direct Investment, Intrafirm Trade, and Ownership Structure.” European Economic Review, Vol. 45 (2001), pp. 475-494.

Lommerud, K.E. And SøRGard, L. "Merger and Product Range Rivalry.” International Journal of Industrial Organization, Vol. 16 (1997), pp. 21-42.

- Meland, F., And Sørgard, L. "Unionised Oligopoly, Trade Liberalisation and Location Choice.” Economic Journal, Vol. 113 (2003), pp. 782-800.

, Straume, O.R., AND Sørgard, L. “Downstream Merger with Upstream Market Power.” European Economic Review, Vol. 49 (2005), pp. 717-743.

Long, N.V. And Vousden, N. "The Effects of Trade Liberalization on Cost Reducing Horisontal Mergers." Review of International Economics, Vol. 3 (1995), pp. 141-155.

Marginson, P. And Schulten, T. "The Europeanisation of Collective Bargaining." EIROnline, July 28, 1999. Available at www.eiro.eurofound.eu.int/1997/07. AND —. Towards European Collective Bargaining? IRRU Briefing no. 6, Warwick Business School, 2000.

McGuckin, R.H. AND NGUYEN, S.V. “The Impact of Ownership Changes: A View from the Labor Markets.” International Journal of Industrial Organization, Vol. 19 (2001), pp. 739-762.

Munch, J.R. And SkaKsen, J.R. “Product Market Integration and Wages in Unionized Countries.” Scandinavian Journal of Economics, Vol. 104 (2002), pp. 289-299.

NAYLOR, R. "International Trade and Economic Integration When Labour Markets Are Generally Unionised.” European Economic Review, Vol. 42 (1998), pp. 1251-1267.

NEARY, J.P. "Globalisation and Market Structure.” Journal of the European Economic Association, Vol. 1 (2003), pp. 245-271.

—. "Cross-Border Mergers as Instruments of Comparative Advantage." Manuscript, University College Dublin, 2004.

Nilssen, T. ANd Sørgard, L. “Sequential Horizontal Mergers.” European Economic Review, Vol. 42 (1998), pp. 16831702.

Norbäck, P.-J. And Persson, L. "Privatization and Foreign Competition.” Journal of International Economics, Vol. 62 (2004), pp. 409-416.

Organization for Economic Cooperation and Development (OECD). Economic Performance and the Structure of Collective Bargaining. Chapter 3, "Employment Outlook," 1997.

Oswald, A. "The Economics of Trade Unions: An Introductory Survey.” Scandinavian Journal of Economics, Vol. 87 (1985), pp. 166-193.

Paparella, D. "Agreement on Productivity and Employment Signed at Zanussi." EIROnline, December 28, 1997. Available at www.eiro.eurofound.eu.int.

Peoples, J., Hekmat, A., And Moini, A.H. “Corporate Mergers and Union Wage Premiums.” Journal of Economics and Finance, Vol. 17 (1993), pp. 65-75.

Pemberton, J. “A 'Managerial' Model of the Trade Union.” Economic Journal, Vol. 98 (1988), pp. 755-771.

Perry, M.K. AND Porter, R.H. “Oligopoly and the Incentive for Horizontal Mergers.” American Economic Review, Vol. 75 (1985), pp. 219-227.

(c) RAND 2006. 
Richardson, M. “Trade and Competition Policies: Concordia Discors?” Oxford Economic Papers, Vol. 51 (1999), pp. $649-664$.

SAGGI, K. AND YILDIZ, H.M. "On the International Linkages Between Trade and Merger Policies.” Review of International Economics, Vol. 14 (2006), pp. 212-225.

Salant, S.W., Switzer, S., and Reynolds, R.N. "Losses from Horizontal Merger: The Effects of an Exogenous Change in Industry Structure on Cournot-Nash Equilibrium.” Quarterly Journal of Economics, Vol. 98 (1983), pp. 185-199.

Singh, N. AND Vives, X. "Price and Quantity Competition in a Differentiated Duopoly." RAND Journal of Economics, Vol. 15 (1984), pp. 546-554.

Spearot, A.C. "Equilibrium Horizontal and Vertical Mergers in an International Oligopoly." Manuscript, University of Wisconsin-Madison, 2004.

Straume, O.R. "Union Collusion and Intra-Industry Trade.” International Journal of Industrial Organization, Vol. 20 (2002), pp. 631-652.

- "International Mergers and Trade Liberalisation: Implications for Unionised Labour." International Journal of Industrial Organization, Vol. 21 (2003), pp. 717-735.

SørGard, L. "Domestic Merger Policy in an International Oligopoly: The Nordic Market for Electricity." Energy Economics, Vol. 19 (1997), pp. 239-253.

UNCTAD. Cross Border Mergers and Acquisitions and Development. United Nations: World Investment Report, 2000. . Transnational Corporations and Export Competitiveness. United Nations: World Investment Report, 2002.

Werden, G.J. "A Robust Test for Consumer Welfare Enhancing Mergers Among Sellers of Differentiated Products." Journal of Industrial Economics, Vol. 44 (1996), pp. 409-413.

YILDIZ, H.M. "National Versus International Mergers and Trade Liberalization.” Manuscript, Southern Methodist University, Dallas, 2003. 